\title{
Evaluating the Level of Diffusion of Social Networking Sites among Malaysian University Students
}

\author{
Mohamed Amin Embi ${ }^{1}$, Serge Gabarre ${ }^{2}$, Cécile Gabarre ${ }^{2}$, Afendi Hamat ${ }^{3} \&$ Rosseni Din ${ }^{1}$ \\ ${ }^{1}$ Faculty of Education, Universiti Kebangsaan Malaysia, Bangi, Malaysia \\ ${ }^{2}$ Faculty of Modern Languages and Communication, Universiti Putra Malaysia, Serdang, Malaysia \\ ${ }^{3}$ Faculty of Social Sciences and Humanities, Universiti Kebangsaan Malaysia, Bangi, Malaysia \\ Correspondence: Serge Gabarre, Faculty of Modern Languages and Communication, Universiti Putra Malaysia, \\ 43400 UPM Serdang, Malaysia. Tel: 60-3-8946-8945. E-mail: serge@upm.edu.my
}

Received: October 13, 2013 Accepted: December 16, 2013 Online Published: January 27, 2014

doi:10.5539/ass.v10n3p99 URL: http://dx.doi.org/10.5539/ass.v10n3p99

\begin{abstract}
Although Malaysians have been reported to be the heaviest social networking users, no survey had been conducted in the country to evaluate the level of diffusion of these sites. A nation-wide survey was conducted during two months to evaluate the membership, usage pattern, and perceptions of social networking sites among 6498 Malaysian university students. This article provides descriptive statistics and interprets the results in light of current literature and similar surveys conducted in other countries. Results revealed that a large majority of students were members of Facebook which they used on a daily basis mostly, but not exclusively to connect with their friends. The article concludes with opportunities to include such sites in formal and informal learning.
\end{abstract}

Keywords: social networking sites, Malaysian students, perception, usage pattern

\section{Introduction}

\subsection{Purpose of the Research}

For numerous social networking sites (SNSs) members, surfing through the network is predominantly a pastime (Barker, 2009) and a way to connect with old acquaintances (2011). Ji et al. (2010) discovered that cultural differences existed between users of SNSs in Asia and in America. In their online survey, Chinese and Koreans reported that they used SNSs to connect while Americans stated using them to communicate. Insufficient studies suggest this trend may be generalized to all Asian users and to Malaysian users in particular. Research conducted on Facebook in Malaysia with 300 students from a public university found that less than one in two students had an account on this specific SNS (Kabilan, Ahmad \& Abidin, 2010). In the same year, a BBC article commented a TNS study which revealed that Malaysian SNSs' users had the highest numbers of online friends (BBC News Technology, 2010). Following a global growth in SNSs popularity (Cheung, Chiu \& Lee, 2011), Malaysia's number of Facebook users surpassed the 12 million mark (TechCentral, 2011). In 2007, boyd and Ellison highlighted the lack of research on SNSs' users and usage especially outside of the United States. Six years later, nation-wide data on SNSs use in Malaysia among students was still not available. The purpose of this research was to gain information on the Malaysian university students' use of SNSs, their perception, and explore potential for integrating SNSs in education.

\subsection{Review of the Literature}

Social networking sites (SNSs) such as Facebook, MySpace or Friendster have become increasingly popular over the past years. In their history of SNSs, boyd and Ellison (2007) related the genesis of these sites with the advent of Six Degrees.com in 1997. Fifteen years later, Facebook has become the world's largest online social networking site with 1.11 billion active members (Facebook, 2013). While boyd and Ellison (2007) chose to use the term social network sites as opposed to social networking sites in order not to focus on the "relationship initiation" (p. 211), we elected to employ the latter with the aim to emphasize the dynamic nature of these systems. Barker (2009) defines SNSs as "web sites where users can create a profile and connect that profile to others to form an explicit personal network" (p. 209). This definition was completed by Baker and White (2011) who added that SNSs "also act as online diaries. Members are able to chat with each other online, share photos and videos, and also post comments in online forums, blogs, or discussion groups" (p. 396). 
Features offered by SNSs are increasingly varied and powerful. It is undeniable that harnessing the features of these SNSs to replace or complement universities' learning management systems (LMS) warrants further exploration (Selwyn, 2007). Indeed, recent research (Gabarre, Gabarre, Rosseni, Parilah \& Aida, 2013; Goodband, Solomon, Samuels, Lawson, \& Bhakta, 2012; Wang, Woo, Quek, Yang \& Liu, 2011) have suggested the potential these networks could offer for education. Studies relating to Malaysian students' use of LMS have demonstrated their wide distribution, popularity and effectiveness in teaching (Hamat, Embi \& Sulaiman, 2011; Gabarre \& Gabarre, 2012). Consequently, it is anticipated that should SNSs effectively supplement features provided by LMS, popular sites such as Facebook could readily be incorporated in courses offered by Malaysian universities. However, without sufficient knowledge on the Malaysian SNSs users, applications for educations could remain limited.

\section{Method}

\subsection{Instrument}

A 32-item questionnaire adapted from the relevant literature (Caruso \& Salaway, 2008; Doğruer, et al., 2011; Fuchs, 2010; Grosseck, Bran \& Tiru, 2011; Ophus \& Abbitt, 2009; Yu, Tian, Vogel \& Kwok, 2010) was designed to investigate the Malaysian students' use of SNSs. These items were divided among five sections in order to gain more specific information on the students' (1) background, (2) Internet usage pattern, (3) SNSs membership, (4) SNSs usage pattern, and (5) SNSs perception. From the 32 items, eight allowed the respondents to provide additional information by answering open-ended questions. Subsequently, the questionnaire was reviewed by five experts in the fields of education and the social sciences who examined the face and content validity of the items. To further validate the instrument, a pilot study was carried out with 37 Malaysian students. Subsequently, findings from the pilot study were used to amend the questionnaire (Hamat, Embi \& Hassan, 2012). The SNSs perception construct was subjected to a post-hoc reliability evaluation with a random sample consisting of 30 respondents. The SNSs engagement scale revealed a good internal consistency, with a Cronbach alpha coefficient reported of .87. Pallant (2007) citing DeVellis (2003) indicated that the Cronbach alpha of a scale should be above .7 to indicate a good internal consistency.

\subsection{Research Design}

In order to administer the questionnaire to a national sample, the researchers used the SurveyMonkey online service. The reasons an online service was used are threefold. First, SurveyMonkey was relatively easy to use as it enabled the users to upload the items in a simple format. Second, using an online service eliminated the need to rely on enumerators to manually key-in the responses and thus reduced the likelihood of erroneously entered data. Third, an online service offered the possibility to cost-effectively distribute the questionnaire to all parts of Malaysia, and furthermore reduced the bias which might have been created if it had only been circulated in selected universities. The questionnaire was advertised in all Malaysian institution of higher learning. A message was posted on the respective learning management systems and bulletin boards with the mention that respondents would be eligible for a lucky draw to win an iPod touch and ten portable hard disks. The questionnaire was available online for two months. A descriptive analysis of frequencies and cross tabulations of the collected data was carried out using SPSS 16. As argued by Norman (2010), and due to the grammatical and numerical symmetry employed in the Likert scales, the data obtained was assumed to be interval in order to obtain mean and standard deviation values. The present article reports on these results related to (1) the respondents' background, (2) SNSs membership, (3) SNSs usage pattern, and addresses (4) SNSs perceptions.

\subsection{Limitations}

As with all research, this study contains a number of inherent limitations. The first limitation was related to the respondents as this study only focuses on Malaysian students enrolled in educations of higher learning. Second, this research is limited to a period of two months and thus does not aim to investigate any evolution in the patterns of SNSs usage. Third, the survey was administered online and as such may skew the results as it might not include respondents who did not have access to a connected computer. Consequently, results are non-random as participation was based on an opt-in sampling. This potential sampling bias warrants for additional investigations using different channels to administer the questionnaire. Fourth, as with all surveys, the data collected stems from self-report and accordingly may be prone to accidental or intentional errors. Future studies should attempt to record in-situ activities through the use of monitoring software in order to triangulate the results from the current research. 


\section{Results and Discussion}

\subsection{Respondents' Background}

Table 1. Demographic data of the respondents

\begin{tabular}{lcccc}
\hline & \multicolumn{2}{c}{ Male } & \multicolumn{2}{c}{ Female } \\
& Frequency & Percentage & Frequency & Percentage \\
\hline Graduate & 2415 & $37.2 \%$ & 3362 & $51.7 \%$ \\
Postgraduate & 316 & $4.9 \%$ & 405 & $6.2 \%$ \\
Total & 2731 & $42.0 \%$ & 3767 & $58.0 \%$ \\
\hline
\end{tabular}

$N=6498$. Note: Rounding of values account for discrepancies in the reported totals.

A total of 6498 students participated in the online survey. The size of the sample was sufficient to provide a confidence interval of $\pm 1.2 \%$ for a $95 \%$ confidence level. Such a confidence interval allows generalizations to be made for the whole population. In 2010, the entire population of Malaysian students enrolled in institutions of higher learning was 1134134 students (Malaysia, 2010). As can be viewed in Table 1, a majority of respondents were female (58.0\%), this value is to a certain degree consistent with the population of Malaysian students in institutions of higher learning which consists of more females $(55.2 \%)$ than males. The ratio of graduate to postgraduate students in this survey $(1: 8.0)$ was not too distant from the national average (1:11.8). As a consequence, it can be safely affirmed that the sample represents fairly well the population of Malaysian students.

Table 2. Conditions facilitating active SNSs membership

\begin{tabular}{lcccrc}
\hline & \multicolumn{2}{c}{ Yes } & \multicolumn{2}{c}{ No } & Not answered \\
Do you have: & Frequency & Percentage & Frequency & Percentage & Frequency \\
\hline a computer? & 6350 & $97.7 \%$ & 148 & $2.3 \%$ & 0 \\
access to the Internet? & 6163 & $94.8 \%$ & 335 & $5.2 \%$ & 0 \\
an SNS account? & 5137 & $80.8 \%$ & 1222 & $19.2 \%$ & 139 \\
\hline$N=6498$ & & & &
\end{tabular}

From the 6498 respondents, an overwhelming number of students declared owning a computer. The value of $97.7 \%$ (see Table 2) revealed that practically all respondents had a computer. This figure should be interpreted in light of the limitations mentioned above. Even though a small proportion of students without computers (2.3\%) were able to participate in this survey, it can safely be assumed that those who owned a computer could more easily participate. The same observation can also be applied to the results pertaining to access to the Internet, with $94.8 \%$ of the respondents declaring that they could access the web from their home. The remaining $5.8 \%$ of the students were not able to connect to the Internet where they lived. In the group of 6498 respondents, 5137 declared that they already had an SNS account. This is a significant value with a ratio of slightly more than four out of five respondents who were at the time of the survey members of online networks. These primary national results reveal the impact of SNSs on the population of Malaysian students. However, in spite of the predominant majority who used SNSs it should be noted that close to $20 \%$ of students who took part in the survey declared not being a member of any online networks. Although, 534 respondents $(8.2 \%)$ intended to register with an SNS in the near future, 688 university students $(10.6 \%)$ declared that they did not intend to become members of any SNSs within the following three months. 


\subsection{SNSs Membership}

Table 3. Reasons for not registering on an SNS in the next three months

\begin{tabular}{lcc}
\hline Reasons & Frequency & Percentage \\
\hline I am not interested in SNSs & 288 & $41.9 \%$ \\
I am not aware of SNSs & 200 & $29.1 \%$ \\
I have no need for SNSs & 158 & $23.0 \%$ \\
I have poor Internet skills & 117 & $17.0 \%$ \\
I feel that SNSs are a distraction & 103 & $15.0 \%$ \\
Other reasons & 33 & $4.8 \%$ \\
\hline$N=688$ & &
\end{tabular}

The reasons given, which are enumerated in Table 3, shed some light on their motivations for not registering on any social network. The main explanation was a lack of interest in SNSs, followed by not being aware of SNSs, and not having a need for them. Although further research is required, lack of interest in SNSs has been linked to the desire to not disclose oneself on the Internet, from fears of cybersafety, and to a preference for other forms of distractions (Baker \& White, 2011). Students who stated that they were not aware of SNSs accounted for 29.1\% of respondents who did not register on a network. This proportion stood at $3.1 \%$ from the total respondents who participated in this survey. The fact that this questionnaire was administered online, and thus with users who had at the least a basic understanding about the Internet raised some questions to the reasons for such a proportion. We believe that this value could perhaps be explained by a misunderstanding of the acronym. The non-contracted form for SNSs was spelled out and Facebook was given as an example on the first page of the questionnaire, yet some respondents could have quickly skimmed through the questionnaire's introduction before delving straight to the items. For $17 \%$ of the respondents, poor Internet skills were justified for not having registered on an SNS. Unexpectedly, poor Internet skills and not owning a computer did not cross tabulate, as only seven out 117 respondents declared not owning a computer and having poor Internet skills. Additionally, the same values were obtained when cross tabulating the variables related to having no Internet access with responses to having poor Internet skills.

A cumulative total of $38 \%$ either felt that they did not need SNSs in their lives (23\%) or that they were perceived as distractions (17\%). When combined with the number of students who were not interested in SNSs, this value rose to close to $80 \%$. From the 33 respondents who stated other reasons, nine expressed concerns about privacy and online safety, while others explained that they had grown out of it, felt they didn't need it or were unsure of what they would do with it. The number of students who did not intend to register on SNSs represented a minority in light of the overwhelming majority of SNSs users; nevertheless, these students should be taken into consideration before venturing in learning scenarios where such sites replace more traditional learning management systems.

Table 4. Members and frequent users of different SNSs

\begin{tabular}{lccccc}
\hline & \multicolumn{2}{c}{ Members $(N=5012)$} & & \multicolumn{2}{c}{ Frequent users $(N=4909)$} \\
\cline { 2 - 3 } \cline { 6 - 6 } Social Networking Sites & Frequency & Valid percentage & & Frequency & Valid percentage \\
\hline Facebook & 4970 & $99.2 \%$ & & 4909 & $98.7 \%$ \\
Twitter & 1494 & $29.8 \%$ & & 626 & $12.6 \%$ \\
Friendster & 2436 & $48.6 \%$ & & 179 & $3.6 \%$ \\
Tagged & 863 & $17.2 \%$ & & 169 & $3.4 \%$ \\
MySpace & 1122 & $22.4 \%$ & & 115 & $2.3 \%$ \\
\hline
\end{tabular}

In keeping with what has been described above, a significant proportion of students are members of SNSs. As can be seen in Table 4, an overwhelming majority of Malaysian students who are active users of a social 
networking site use Facebook. Despite the fact that Facebook was not the first SNS on the Internet, as it was only available to the general public nine years after the advent of Six Degree.com (boyd \& Ellison, 2007), it rapidly gained importance as a mean of communication (Ross et al., 2009). As noted by several authors (Ayling \& Hebblethwaite, 2011; Junco, 2012), Facebook is currently the most popular SNS, particularly with students (Click \& Petit, 2010; Hargittai, 2007; Hew, 2011). Recently, Siemens and Weller (2011) noted that general SNSs like Facebook and Twitter tended to be more popular than specialized ones. It is thus not surprising that Twitter comes in second position with more than one in ten active users. Trailing behind, Friendster, Tagged and MySpace each represent less than 4\% of the respondents. These values are consistent with Alexa (2013) which indicates that Facebook is Malaysia's second most accessed web site. Twitter ranks in at number twelve, while Tagged was $83^{\text {rd }}$. Other SNSs, such as Orkut and Tumblr remain marginal with Malaysian students.

It is noteworthy that several students $(15.5 \%)$ declared being frequent members of more than one SNS; consequently, the sum of all the values in Table 4 is greater than $100 \%$. Multiple active memberships on SNSs could be explained by several factors. First, different SNSs cater to different needs. Twitter, for example, with a limit of 140 characters is primarily used for micro-blogging (Kaplan \& Haenlein, 2010), while MySpace has a strong focus on music (Vie, 2008). Second, the social networking site Friendster, which was formerly predominant in Malaysia (boyd \& Ellison, 2007), could still be used concomitantly by some students. The difference between membership and active membership in an SNS can be seen in Table 4, with an alternative ranking of the various sites. Facebook remains the first SNS in terms of membership, but Friendster replaces Twitter in the second position with close to half of all SNSs members. Friendster's discrepancy between the number of members and frequent users could be due to the site's rebranding as a gaming platform from a social network site (Steinberg, 2011), as such a shift in focus might not have satisfied all users' expectations. It is noteworthy to highlight that all SNSs except Facebook had a relative low ratio of frequent users to members. For the micro-blogging site Twitter, only $41.9 \%$ of its members were active frequent users. This figure dropped to $19.6 \%$ for Tagged and $10.2 \%$ for MySpace. These values were in contrast with Facebook's level of frequent users to members reaching $98.8 \%$.

Table 5. Duration of SNSs membership

\begin{tabular}{lcc}
\hline Duration & Frequency & Percentage \\
\hline Less than 6 months & 164 & $3.3 \%$ \\
Between 6 months to a year & 576 & $11.5 \%$ \\
Between 1 to 3 years & 3199 & $63.6 \%$ \\
More than 3 years & 1088 & $21.6 \%$ \\
\hline
\end{tabular}

$N=5027$

The vast majority of Malaysian students are not new to the realm of social networking as $85.2 \%$ of them have been members for more than one year (see Table 5). This is a cumulative value which includes the $21.6 \%$ of students who have been members for more than three years. We believe that a period of at least six months is an adequate time to be accustomed to SNSs practices, and thus enabled the respondents to properly describe their perceptions as well as patterns of SNSs usage. This was the case for $96.7 \%$ respondents. Past observations have revealed that individuals who were not members of SNSs joined a network when they entered university (Gabarre \& Gabarre, 2010). In these cases the SNS was primarily used to communicate and to connect with friends and family. Although additional research is required, this could perhaps be the case for the remaining $3.3 \%$ respondents who had been members of SNSs for less than 6 months. 


\subsection{SNSs Usage Pattern}

Table 6. Time spent per day on the SNSs

\begin{tabular}{lcl}
\hline Duration & Frequency & Valid percentage \\
\hline Less than 1 hour & 873 & $17.4 \%$ \\
Between 1 to 2 hours & 1626 & $32.3 \%$ \\
Between 2 to 3 hours & 1101 & $21.9 \%$ \\
More than 3 hours & 1427 & $28.4 \%$ \\
\hline
\end{tabular}

The students were asked to state the amount of time they spent per day on all of their social networking sites. The majority $(82.6 \%)$ spent more than one hour with close to one third $(28.4 \%)$ of the group spending more than three hours per day on an SNS (see Table 6). A minority of users (17.4\%) spent less than one hour per day on their SNSs. A cross tabulation of these values with those from Table 5 revealed that the majority of novice users (less than 6 months) spent less than one hour per day on their SNSs, while the majority of experienced users (more than 3 years) spent more than three daily hours accessing their network. On the other hand, the majority of intermediate users (between 6 months to 3 years) spent between one to two hours a day on their SNSs. This trend could perhaps be explained by the maturity and size of the individual networks. New users might not have fully developed their networks and consequently might not have spent as much time reviewing their friends' activities. In contrast, students who had been active on SNSs for a longer period of time could perhaps have had larger networks of friends, and consequently could have required more time to view status updates. This could be investigated in a future research where users would be queried on their numbers of online friends, on the duration that they have been members, on the growth of their networks, and on the time and type of activities carried out on their SNSs. Similarly to another study (Junco \& Cotten, 2012), the respondents in the present survey did not specify whether they were multitasking while being connected to their SNSs. The students could have opened the networking site in one window in the background while surfing on other sites or even performing others tasks with their computers. As such, time spent per day on the SNSs could be more accurately interpreted as time when the students had permanent access to their online networks, even though it might not have been exclusive.

Table 7. Time of day when the students access the SNSs

\begin{tabular}{lcc}
\hline Time of day & Frequency & Valid percentage \\
\hline 12:00 a.m. to 03:00 a.m. & 379 & $7.5 \%$ \\
03:00 a.m. to 06:00 a.m. & 34 & $0.7 \%$ \\
06:00 a.m. to 09:00 a.m. & 136 & $2.7 \%$ \\
09:00 a.m. to 12:00 p.m. & 375 & $7.5 \%$ \\
12:00 p.m. to 03:00 p.m. & 195 & $3.9 \%$ \\
03:00 p.m. to 06:00 p.m. & 225 & $4.5 \%$ \\
06:00 p.m. to 09:00 p.m. & 679 & $13.5 \%$ \\
09:00 p.m. to 12:00 a.m. & 3004 & $59.8 \%$ \\
\hline
\end{tabular}

$N=5027$

One item of the survey pertained to the time of the day when the students accessed the SNSs. For practical reasons the day was divided in eight segments of three hours, and the students were required to select the time when they mostly used their SNSs. As can be seen in Table 7, the pattern of usage of SNSs followed the expected rhythm of life with the fewest active users from 3:00 a.m. to 6:00 a.m. and with low values during the day when most students attended classes. Close to $60 \%$ of the students accessed their SNSs between 9:00 p.m. and 12:00 p.m. In general, this was a time when there were fewer classes and thus when students had more free 
time. For a majority of students $(65.2 \%)$ who resided on campus, their laptop and the Internet were often perceived as a distraction after a day of studies (Barker, 2009). This could in part explain the predominance of the evening shift in the usage trends. In a study on students' use of Facebook in Romania, Grosseck, Bran and Tiru (2011) obtained similar results with more than $60 \%$ of their respondents accessing Facebook between 6:00 p.m. and 10:00 p.m. Similarly, Facebook was least accessed in the early morning.

Table 8. Number of times the SNSs are accessed per day

\begin{tabular}{lcc}
\hline Number of times & Frequency & Valid percentage \\
\hline 1 to 2 times & 1769 & $35.2 \%$ \\
3 to 4 times & 1881 & $37.4 \%$ \\
5 to 6 times & 563 & $11.2 \%$ \\
More than 6 times & 814 & $16.2 \%$ \\
\hline
\end{tabular}

$N=5027$

Table 8 displays the trend of connections to SNSs per day. The majority of students connected to their SNSs between three to four times per day (37.4\%). Those who connected one to two times daily were almost as numerous (35.2\%), while those who connected more than five times per day amounted to just over a quarter of respondents $(27.4 \%)$. Cumulatively, students predominantly (64.8\%) connect to their SNSs of choice at least 3 times within 24 hours. This figure reveals that Malaysian students were extremely well connected as they frequently checked-in with their network. Although the present survey did not investigate the duration of each connection, Grosseck, Bran, and Tiru (2011) reported that the majority of Facebook users connected frequently but for a short duration. This could perhaps also be the case with Malaysian students who frequently connected to review their friends' status or update their own. A similar study conducted in Turkey puts in perspective the Malaysian students' frequency of use as Kayri and Çakır (2010) reported that only $31 \%$ of the students they investigated connected to Facebook on a daily basis, while a majority of $55 \%$ logged-in on a weekly basis.

Table 9. With whom do you communicate the most using your SNSs?

\begin{tabular}{lcc}
\hline & Frequency & Valid percentage \\
\hline Friends & 3876 & $77.1 \%$ \\
Course-mates & 842 & $16.7 \%$ \\
Family & 155 & $3.1 \%$ \\
Girlfriend, boyfriend & 88 & $1.8 \%$ \\
Lecturers & 9 & $0.2 \%$ \\
Others & 57 & $1.1 \%$ \\
\hline$N=5027$ & &
\end{tabular}

It has been reported above that Malaysian students were particularly well connected with their social network. The data in Table 9 shows that in these networks, the respondents predominantly connected with their friends (77.1\%). Course-mates $(16.7 \%)$ and family members (3.1\%) came in respectively in second and third place. It is interesting to note that communication with lecturers was not a priority for the group under investigation. These values do not infer that communication with lecturers did not occur, but instead affirm that educators were not the primary interlocutors with whom students interacted on their SNSs. Indeed, only 9 students responded that they mostly communicated with their lecturers on their SNSs. Such findings are consistent with Baran (2010) as well as with Ophus and Abbitt (2009) who reported that a majority of students did not wish to interact with their lecturers on SNSs. Furthermore, students communicated less readily with their families than with their friends or classmates on their SNSs. It is possible that students favored different channels to communicate with their families or lecturers, such as emails or phone calls. In several studies (Elllison, Vitak, Steinfield, Gray, \& Lampe, 2011; Lampe, Ellison, \& Steinfield, 2008; Madge, Meek, Wellens, \& Hooley, 2009), researchers discovered that students would not include their family members in their network of friends on their SNSs in order to shield their 
student lives from their parents and maintain a certain level of privacy. This could also be the case for Malaysian students.

Table 10. Applications and activities mostly used on the SNSs

\begin{tabular}{|c|c|c|c|c|c|c|c|}
\hline \multirow[b]{2}{*}{ Applications activities } & \multicolumn{4}{|c|}{ Not used } & \multicolumn{3}{|l|}{ Most used } \\
\hline & 1 & 2 & 3 & 4 & 5 & $M$ & $S D$ \\
\hline Checking on friends & $4.1 \%$ & $15.3 \%$ & $28.2 \%$ & $30.3 \%$ & $22.2 \%$ & 3.5 & 1.1 \\
\hline Status updates & $6.6 \%$ & $22.8 \%$ & $24.9 \%$ & $22.8 \%$ & $22.9 \%$ & 3.3 & 1.2 \\
\hline Messaging emailing & $5.9 \%$ & $21.4 \%$ & $31.5 \%$ & $26.7 \%$ & $14.5 \%$ & 3.2 & 1.1 \\
\hline Chatting & $9.0 \%$ & $26.1 \%$ & $30.3 \%$ & $22.6 \%$ & $12.1 \%$ & 3.0 & 1.2 \\
\hline Photo sharing tagging & $9.5 \%$ & $27.4 \%$ & $28.6 \%$ & $20.2 \%$ & $14.3 \%$ & 3.0 & 1.2 \\
\hline Games applications & $40.9 \%$ & $27.9 \%$ & $14.9 \%$ & $9.3 \%$ & $7.0 \%$ & 2.1 & 1.2 \\
\hline Blogging micro-blogging & $47.2 \%$ & $22.4 \%$ & $14.7 \%$ & $9.5 \%$ & $6.2 \%$ & 2.0 & 1.2 \\
\hline
\end{tabular}

Regarding the applications and activities mostly used when on their SNSs, the students responded to using the sites primarily to check on friends and to carry out status updates. Table 10 reveals that a significant proportion of the respondents did not use games and applications on their SNSs. These findings were somehow unexpected as it had been reported that "the main demographic for computer game playing was 20-35 year-olds" (Kirschner \& Karpinski, 2010, p. 1238). Such findings are noteworthy for potential use of SNSs in education, as authors such as Donmus (2010) advocated using SNSs based gaming in foreign language learning scenarios. This approach is legitimate as it taps on the students' interest to stimulate motivation leading to learning. Furthermore, Kabilan, Ahmad, and Abidin (2010) reported that gaming could improve the level of English proficiency of Malaysian students as most SNSs games used this language. Still, it appears that this would not be the best course with the respondents of this survey in view of their apparent lack of interest in gaming. Although Bicen and Cavus (2011) reported that checking on friends and communicating with them were the principal activities on SNSs, they also noted that games were moderately used by students. This report partly contradicts our findings. Several authors (Junco, 2012; Valenzuela, Park, \& Kee, 2009) reported a dichotomy between communicative activities such as messaging and status updates, and non-communicative activities such as gaming and checking on friends. Using the same definition, we noted that Malaysian students appeared to be dynamically involved in specific communicative activities such as messaging and chatting, but relinquished blogging and micro-blogging. Similarly, the respondents revealed a predilection for a specific form of the non-communicative activity of checking on friends while at the same time were less involved in other passive activities like gaming and using applications. The seemingly lack of popularity of blogging and micro-blogging is partly visible in Table 4, where although respondents were members of Twitter, only 626 did actively use this SNS. Although additional investigation could clarify this matter, it is possible that the respondents used dedicated blogging sites to express themselves rather than SNSs which have inherent limitations. Twitter only allows users to post messages of 140 characters, while Facebook's wall was mostly designed to cater to status updates and as such does not currently promote full scale blogging. 
Table 11. Purpose for using the SNSs

\begin{tabular}{|c|c|c|c|c|c|c|c|}
\hline \multirow[b]{2}{*}{ Purpose } & \multicolumn{3}{|c|}{ Least frequent } & \multicolumn{2}{|c|}{ Most frequent } & \multirow[b]{2}{*}{$M$} & \multirow[b]{2}{*}{$S D$} \\
\hline & 1 & 2 & 3 & 4 & 5 & & \\
\hline Keeping in touch with current friends & $1.4 \%$ & $4.7 \%$ & $13.9 \%$ & $26.0 \%$ & $54.0 \%$ & 4.3 & 1.0 \\
\hline Communicating with current classmates & $2.4 \%$ & $6.3 \%$ & $16.4 \%$ & $31.4 \%$ & $43.5 \%$ & 4.1 & 1.0 \\
\hline $\begin{array}{l}\text { Connecting with people I have lost touch } \\
\text { with }\end{array}$ & $3.3 \%$ & $9.1 \%$ & $22.9 \%$ & $33.6 \%$ & $31.1 \%$ & 3.8 & 1.1 \\
\hline $\begin{array}{l}\text { Discussing information related to courses } \\
\text { taken at university }\end{array}$ & $4.8 \%$ & $11.0 \%$ & $23.0 \%$ & $31.1 \%$ & $30.1 \%$ & 3.7 & 1.1 \\
\hline $\begin{array}{l}\text { Sharing information about courses at } \\
\text { university }\end{array}$ & $5.3 \%$ & $11.1 \%$ & $25.3 \%$ & $30.0 \%$ & $28.2 \%$ & 3.6 & 1.2 \\
\hline $\begin{array}{l}\text { Letting others know about what is } \\
\text { happening in my life }\end{array}$ & $12.8 \%$ & $19.9 \%$ & $27.4 \%$ & $23.9 \%$ & $16.0 \%$ & 3.1 & 1.3 \\
\hline Entertainment (e.g. playing online games) & $40.1 \%$ & $22.0 \%$ & $16.5 \%$ & $12.1 \%$ & $9.2 \%$ & 2.3 & 1.3 \\
\hline $\begin{array}{l}\text { Showing my creativity (e.g. writings, } \\
\text { photos, songs) }\end{array}$ & $41.6 \%$ & $24.4 \%$ & $17.4 \%$ & $10.0 \%$ & $6.6 \%$ & 2.2 & 1.2 \\
\hline $\begin{array}{l}\text { Making money (e.g. conducting online } \\
\text { business) }\end{array}$ & $71.6 \%$ & $14.2 \%$ & $7.8 \%$ & $3.9 \%$ & $2.5 \%$ & 1.5 & 1.0 \\
\hline
\end{tabular}

The results pertaining to the purpose of using the SNSs as set in Table 11 coincide to some degree with what has been described above. The students mainly used their SNSs to keep in touch or connect with their friends. Communication with current classmates was also frequently carried out on the SNSs. As such, the online network was mainly used to strengthen the offline relations (Ayling \& Hebblethwaite, 2011; Barker, 2009). A similar pattern of usage has been described in a different context by Hsu, Wang, and Tai (2011) who noted that SNSs users mostly interacted with their close friends rather than mere acquaintances. Consequently, the offline and online social structures have become practically indistinct (Tokunaga, 2011, p. 430). For these reasons, it is not surprising to observe that SNSs were also used by university students to reconnect with friends from primary or secondary schools. DeAndrea, Ellison, LaRose, Steinfield, and Fiore (2012) referred to this need to connect with old friends as "friendsickness" (p. 19). They explained that the SNSs played an important role in helping university students adapt to their new environment by maintaining a connection with former friends during the transitional phase of constructing a network of new friends. The topic of courses taken at university was recurrent as a majority of students reported frequently discussing it and sharing information about this subject. A majority of respondents answered that they did not use their SNSs for entertainment such as online gaming. This is consistent with the results described above. However, recent literature (Barker, 2009; Doğruer et al., 2011; Hew, 2011; Valenzuela et al., 2009) clearly demonstrated that SNSs were commonly used to pass time and were perceived as a form of entertainment. The discrepancy with the results from the present survey could mean that the respondents chose not to use SNSs for entertainment and focused primarily on communicative activities. Alternatively, this value could have been influenced by the example of gaming which was given in the definition of entertainment, and perhaps skewed the responses. Additional examples of forms of entertainment could perhaps have altered the results as respondents might have gained a better understanding of the possible activities encompassed by this term. Results from this survey revealed that SNSs were seldom used by the students to display their creativity and even more rarely to conduct online businesses. The former revealed that the moderate use of photo sharing and tagging as seen in Table 10, could in fact be due to the sharing of others' pictures as opposed to photographs taken by the SNSs users. The findings regarding the activity of conducting businesses were in line with previous research (Yusof, Sandhu, \& Jain, 2008) revealing that although $85 \%$ of Malaysian students were motivated to start their own business, this venture would only start after they had completed their studies. 


\subsection{SNSs Perception}

Table 12. Perceived SNSs engagement

\begin{tabular}{|c|c|c|c|c|c|c|c|}
\hline \multirow[b]{2}{*}{ Purpose } & \multicolumn{3}{|c|}{ Strongly disagree } & \multicolumn{2}{|c|}{ Strongly agree } & \multirow[b]{2}{*}{$M$} & \multirow[b]{2}{*}{$S D$} \\
\hline & 1 & 2 & 3 & 4 & 5 & & \\
\hline I must log in to my SNSs at least once a day & $10.8 \%$ & $13.5 \%$ & $20.2 \%$ & $24.9 \%$ & $30.6 \%$ & 3.5 & 1.3 \\
\hline SNSs have become a part of my daily life & $7.5 \%$ & $15.1 \%$ & $24.4 \%$ & $28.5 \%$ & $24.6 \%$ & 3.5 & 1.2 \\
\hline I feel that I am part of my SNSs community & $5.9 \%$ & $14.6 \%$ & $29.4 \%$ & $30.7 \%$ & $19.4 \%$ & 3.4 & 1.1 \\
\hline I would be sorry if my SNSs shut down & $13.5 \%$ & $18.5 \%$ & $26.5 \%$ & $22.8 \%$ & $18.6 \%$ & 3.1 & 1.3 \\
\hline I am proud to tell people I'm on an SNS & $14.0 \%$ & $16.9 \%$ & $33.7 \%$ & $19.9 \%$ & $15.5 \%$ & 3.1 & 1.2 \\
\hline
\end{tabular}

The data displayed in Table 12 highlights the perceived SNSs engagements of Malaysian students. It is clearly visible that a majority of respondents agreed that SNSs usage had become engrained in their lives. Most students had to $\log$ in at least once a day as seen above in Table 8 . Furthermore $53.1 \%$ of the students stated that the SNSs had become a part of their lives. This specific trend was not exclusive to Malaysian students as others have reported similar findings in other countries. It has been reported that SNSs have become part of the daily lives of Americans (Chen \& Bryer, 2012), Romanians (Grosseck et al., 2011) and Turks (Mazman \& Usluel, 2010). These observations lead to some questioning regarding SNSs addiction. Increasingly, some SNSs users have difficulty staying away from their networks and develop an addiction to checking-in to the website (Loving \& Ochoa, 2011; Saljooghi, 2011). This is particularly true with Facebook leading to the creation of the term "Facebook addict" (Kaplan \& Haenlein, 2010, p. 64). Only 18.6\% of the respondents from this survey strongly agreed that they would be sorry if their SNSs shut down, thus suggesting that the majority of Malaysian students were not at the addiction stage of SNSs usage. The feeling of belonging to a community was shared by $50.1 \%$ of the respondents, which hints at the link between social networking and the construction of online and offline social capital as described by Elllison, Vitak, Steinfield, Gray, and Lampe (2011) and Brandtzæg (2012). Additionaly, Nadkarni and Hofmann (2012) reported the need to belong as one of two "primary needs" (p. 243) motivating the use of Facebook. Pride ranked the lowest in the perceived SNS engagement construct probably highlighting the mundane perception of the SNS, as a vast majority of students were members of such sites. Lampe, Ellison, and Steinfield in their 2008 report on students at the Michigan State University, measured the feeling of pride towards being on Facebook. At the time, Facebook was still relatively new and still held an aura of exclusiveness which has mostly vanished today. The mean value of pride on a 5-point Likert scale was recorded at 3.34, which was a slightly higher value in comparison to the measurement performed three years later with Malaysian students.

\section{Conclusion}

Results from this survey enable us to sketch the portrait of the Malaysian student and his relationship with SNSs. The archetype Malaysian student is a female undergraduate who owns a computer, has access to the Internet where she lives, and is already a member of an SNS. She currently is a member of only one SNS, which is Facebook, but has several friends who are still members of Friendster although they no longer use it. She has been an active Facebook member for the past two years, and everyday connects to the network for about an hour and a half in the later part of the evening. Facebook has become part of her daily life and she feels that she must connect at least once per day. Normally, she connects about three times per day mainly to communicate with her friends, checks their status and on some occasions discusses topics related to the courses she attends at university. Although she uses her SNS to communicate with current friends, she also at times uses it to connect with former classmates from her previous school.

The Malaysian students are relatively well connected to the Internet and more specifically to their SNSs. Connections to their network are currently neither ubiquitous nor permanent, and follow a pattern of usage closely related to their life cycles. As such, connections are mainly established in the evening when the students return to their homes or residential colleges. If SNSs were to be used in educational scenarios, this current restriction would have to be taken into account. At the present, the levels of equipment and engagement in SNSs permit informal learning, especially considering that a large majority of students are already members of the 
same network, and readily communicate with their classmates. Tapping into this engagement for formal learning would require a similar commitment from lecturers and optimally support from institutions of higher learning. Research in the United States has revealed that lecturers were not as ready as students to include SNSs in the classroom (Roblyer, McDaniel, Webb, Herman, \& Witty, 2010). Further research pertaining to this matter in Malaysian institutions of higher learning is required in order to assess the Malaysian lecturers' readiness to use this technology. The question of integrating SNSs for formal learning is the subject of stimulating debates (Selwyn, 2009). As observed by Caruso and Salaway, universities "need to explore this question and decide how to proceed" (2008, p. 4).

\section{References}

Alexa. (2013). Top Sites in Malaysia. Alexa The Web Information Company. Retrieved September 30, 2013, from http://www.alexa.com/topsites/countries/MY

Ayling, D., \& Hebblethwaite, D. (2011). Facebook: From offline to online communities of practice in practice-based learning. Paper presented at the NZACE Conference, Napier, New Zealand.

Baker, R., \& White, K. (2011). In their own words: Why teenagers don't use social networking sites. Cyberpsychology, Behavior, and Social Networking, 14(6), 395-398. http://dx.doi.org/10.1089/cyber.2010.0016

Baran, B. (2010). Facebook as a formal instructional environment. British Journal of Educational Technology, 41(6), E146-E149. http://dx.doi.org/10.1111/j.1467-8535.2010.01115.x

Barker, V. (2009). Older adolescents' motivations for social network site use: The influence of gender, group identity, and collective self-esteem. CyberPsychology \& Behavior, 12(2), $209-213$. http://dx.doi.org/10.1089/cpb.2008.0228

BBC News Technology. (2010, October 10). Japanese have fewest digital friends on social networks. Retrieved from http://www.bbc.co.uk

Bicen, H., \& Cavus, N. (2011). Social network sites usage habits of undergraduate students: Case study of Facebook. Procedia - Social and Behavioral Sciences, 28, 943-947. http://dx.doi.org/10.1016/j.sbspro.2011.11.174

Boyd, D. M., \& Ellison, N. B. (2007). Social network sites: Definition, history, and scholarship. Journal of Computer-Mediated Communication, 13(1), 210-230. http://dx.doi.org/10.1111/j.1083-6101.2007.00393.x

Brandtzæg, P. B. (2012). Social networking sites: Their users and social implications - A longitudinal study. Journal of Computer-Mediated Communication, 17(4), 467-488.

Caruso, J. B., \& Salaway, G. (2008). The ECAR study of undergraduate students and information technology, 2008. Boulder, CO: EDUCAUSE Center for Applied Research. http://dx.doi.org/10.1111/j.1083-6101.2012.01580.x

Chen, B., \& Bryer, T. (2012). Investigating instructional strategies for using social media in formal and informal learning. The International Review of Research in Open and Distance Learning, 13(1), 87-104.

Cheung, C. M. K., Chiu, P. Y., \& Lee, M. K. O. (2011). Online social networks: Why do students use Facebook? Computers in Human Behavior, 27, 1337-1343. http://dx.doi.org/10.1016/j.chb.2010.07.028

Click, A., \& Petit, J. (2010). Social networking and Web 2.0 in information literacy. The International Information \& Library Review, 42, 137-142. http://dx.doi.org/10.1016/j.iilr.2010.04.007

DeAndrea, D. C., Ellison, N. B., LaRose, R., Steinfield, C., \& Fiore, A. (2012). Serious social media: On the use of social media for improving students' adjustment to college. Internet and Higher Education, 15, 15-23. http://dx.doi.org/10.1016/j.iheduc.2011.05.009

Devellis, R. F. (2003). Scale development: Theory and applications. Thousand Oaks, CA: Sage.

Doğruer, N., Meneviş, İ., \& Eyyam, R. (2011). What is the motivation for using Facebook? Procedia Social and Behavioral Sciences, 15, 2642-2646. http://dx.doi.org/10.1016/j.sbspro.2011.04.162

Donmus, V. (2010). The use of social networks in educational computer-game based foreign language learning. Procedia Social and Behavioral Sciences, 9, 1497-1503. http://dx.doi.org/10.1016/j.sbspro.2010.12.355

Elllison, N., Vitak, J., Steinfield, C., Gray, R., \& Lampe, C. (2011). Negotiating privacy concerns and social capital needs in a social media environment. In S. Trepte, \& L. Reinecke (Eds.), Privacy Online: Perspectives on Privacy and Self-Disclosure in the Social Web (pp. 19-32). Berlin, Germany: Springer-Verlag. http://dx.doi.org/10.1007/978-3-642-21521-6_3

Facebook. (2013). Monthly active users. Retrieved September 1, 2013, from https://www.facebook.com/facebook 
Fuchs, C. (2010). Social networking sites and complex technology assessment. International Journal of E-Politics, 1(3), 19-38. http://dx.doi.org/10.4018/jep.2010070102

Gabarre, C., \& Gabarre, S. (2012). Criteria for successfully recruiting online peer-tutors in foreign languages. Asia Pacific Journal of Education, 32(2), 197-223. http://dx.doi.org/10.1080/02188791.2012.684954

Gabarre, S., \& Gabarre, C. (2010). Taking a look at Facebook profiles: Students' choice of pictures. Paper presented at the Malaysia International Conference on Foreign Languages (MICFL 2010), Serdang, Malaysia.

Gabarre, S., Gabarre, C., Rosseni, D., Parilah, S., \& Aida, A. K. (2013). Using Mobile Facebook As An LMS: Exploring Impeding Factors. GEMA Online Journal of Language Studies, 13(3), 99-115.

Goodband, J. H., Solomon, Y., Samuels, P. C., Lawson, D., \& Bhakta, R. (2012). Limits and potentials of social networking in academia: Case study of the evolution of a mathematics Facebook community. Learning, Media and Technology, 37(3), 236-252. http://dx.doi.org/10.1080/17439884.2011.587435

Grosseck, G., Bran, R., \& Tiru, L. (2011). Dear teacher, what should I write on my wall? A case study on academic uses of Facebook. Procedia Social and Behavioral Sciences, 15, 1425-1430. http://dx.doi.org/10.1016/j.sbspro.2011.03.306

Hamat, A., Embi, M. A., \& Hassan, H. A. (2012). The use and perception of social networking sites among Malaysian university students: A pilot study. The International Journal of Learning, 18(7), 153-163.

Hamat, A., Embi, M. A., \& Sulaiman, A. H. (2011). Learning management systems in Malaysian higher education institutions. In M. A. Embi (Ed.), e-Learning in Malaysian higher education institutions: Status, trends, \& challenges (pp. 29-50). Putrajaya, Malaysia: Department of Higher Education Ministry of Higher Education.

Hargittai, E. (2007). Whose space? Differences among users and non-users of social network sites. Journal of Computer-Mediated Communication, 13, 276-297. http://dx.doi.org/10.1111/j.1083-6101.2007.00396.x

Hew, K. F. (2011). Students' and teachers' use of Facebook. Computers in Human Behavior, 27, 662-676. http://dx.doi.org/10.1016/j.chb.2010.11.020

Hsu, C. W. J., Wang, C. C., \& Tai, Y. T. (2011). The closer the relationship, the more the interaction on Facebook? Investigating the case of Taiwan users. Cyberpsychology, Behavior, And Social Networking, 14(7-8), 473-476. http://dx.doi.org/10.1089/cyber.2010.0267

Ji, Y. G., Hwangbo, H., Yi, J. S., Rau, P., Fang, X., \& Ling, C. (2010). The influence of cultural differences on the use of social network services and the formation of social capital. International Journal of Human-Computer Interaction, 26(11-12), 1100-1121. http://dx.doi.org/10.1080/10447318.2010.516727

Junco, R. (2012). The relationship between frequency of Facebook use, participation in Facebook activities, and $\begin{array}{llllll}\text { student engagement. Computers } \quad \& \quad \text { Education, } & \text { 58, }\end{array}$ http://dx.doi.org/10.1016/j.compedu.2011.08.004

Junco, R., \& Cotten, S. R. (2012). No A 4 U: The relationship between multitasking and academic performance. Computers \& Education, 59(2), 505-514. http://dx.doi.org/10.1016/j.compedu.2011.12.023

Kabilan, M. K., Ahmad, N., \& Abidin, M. J. Z. (2010). Facebook: An online environment for learning of English in institutions of higher education? Internet and Higher Education, 13, 179-187. http://dx.doi.org/10.1016/j.iheduc.2010.07.003

Kaplan, A. M., \& Haenlein, M. (2010). Users of the world, unite! The challenges and opportunities of social media. Business Horizons, 53, 59-68. http://dx.doi.org/10.1016/j.bushor.2009.09.003

Kayri, M., \& Çakır, Ö. (2010). An applied study on educational use of Facebook as a Web 2.0 tool: The sample lesson of computer networks and communication. International Journal of Computer Science \& Information Technology, 2(4), 48-58. http://dx.doi.org/10.5121/ijcsit.2010.2405

Kirschner, P. A., \& Karpinski, A. C. (2010). Facebook and academic performance. Computers in Human Behavior, 26, 1237-1245. http://dx.doi.org/10.1016/j.chb.2010.03.024

Lampe, C., Ellison, N., \& Steinfield, C. (2008). Changes in use and perception of Facebook. Paper presented at the 2008 ACM Conference on Computer Supported Cooperative Work, San Diego, CA. http://dx.doi.org/10.1145/1460563.1460675

Loving, M., \& Ochoa, M. (2011). Facebook as a classroom management solution. New Library World, 112(3-4), 121-130. http://dx.doi.org/10.1108/03074801111117023

Madge, C., Meek, J., Wellens, J., \& Hooley, T. (2009). Facebook, social integration and informal learning at university: It is more for socialising and talking to friends about work than for actually doing work. Learning, 
Media and Technology, 34(2), 14-155. http://dx.doi.org/10.1080/17439880902923606

Malaysia, M. O. H. E. (2010). Statistics of higher education of Malaysia. Putrajaya, Malaysia: Ministry of Higher Education Malaysia.

Mazman, S. G., \& Usluel, Y. K. (2010). Modeling educational usage of Facebook. Computers \& Education, 55, 444-453. http://dx.doi.org/10.1016/j.compedu.2010.02.008

Nadkarni, A., \& Hofmann, S. G. (2012). Why do people use Facebook? Personality and Individual Differences, 52, 243-249. http://dx.doi.org/10.1016/j.paid.2011.11.007

Norman, G. (2010). Likert scales, levels of measurement and the "laws" of statistics. Advances in Health Science Education, 15(5), 625-632. http://dx.doi.org/10.1007/s10459-010-9222-y

Ophus, J. D., \& Abbitt, J. T. (2009). Exploring the potential perceptions of social networking systems in university courses. Journal of Online Learning and Teaching, 5(4), 639-648.

Pallant, J. (2007). SPSS survival manual: A step-by-step guide to data analysis usings SPSS for Windows (version 15). Crows Nest, Australia: Allen \& Unwin.

Roblyer, M. D., McDaniel, M., Webb, M., Herman, J., \& Witty, J. V. (2010). Findings on Facebook in higher education: A comparison of college faculty and student uses and perceptions of social networking sites. Internet and Higher Education, 13, 134-140. http://dx.doi.org/10.1016/j.iheduc.2010.03.002

Ross, C., Orr, E. S., Sisic, M., Arseneault, J. M., Simmering, M. G., \& Orr, R. R. (2009). Personality and motivations associated with Facebook use. Computers in Human Behavior, 25, 578-586. http://dx.doi.org/10.1016/j.chb.2008.12.024

Saljooghi, A. (2011). Disparities between new media use and critical engagement. Procedia Social and Behavioral Sciences, 15, 761-764. http://dx.doi.org/10.1016/j.sbspro.2011.03.179

Selwyn, N. (2007). 'Screw Blackboard... do it on Facebook!': An investigation of student's educational use of Facebook. Paper presented at the Poke 1.0 - Facebook social research symposium, London, United Kingdom.

Selwyn, N. (2009). Faceworking: Exploring students' education-related use of Facebook. Learning, Media and Technology, 34(2), 157-174. http://dx.doi.org/10.1080/17439880902923622

Siemens, G., \& Weller, M. (2011). Higher education and the promises and perils of social network. Revista de Universidad y Sociedad del Conocimiento, 8(1), 164-170.

Steinberg, S. (2011). Friendster is dead: Encourages U.S. users to move on. RollingStone.

TechCentral. (2011, December 12). Malaysia hits 12 million Facebook users. Retrieved from http://techcentral.my

Tokunaga, R. (2011). Friend me or you'll strain us: Understanding negative events that occur over social networking sites. Cyberpsychology, Behavior, and Social Networking, 14(7-8), 425-432. http://dx.doi.org/10.1089/cyber.2010.0140

Valenzuela, S., Park, N., \& Kee, K. F. (2009). Is there social capital in a social network site?: Facebook use and college students' life satisfaction, trust, and participation. Journal of Computer-Mediated Communication, 14, 875-901. http://dx.doi.org/10.1111/j.1083-6101.2009.01474.x

Vie, S. (2008). Digital divide 2.0: "Generation M" and online social networking sites in the composition classroom. Computers and Composition, 25, 9-23. http://dx.doi.org/10.1016/j.compcom.2007.09.004

Wang, Q., Woo, H. L., Quek, C. L., Yang, Y., \& Liu, M. (2011). Using the Facebook group as a learning management system: An exploratory study. British Journal of Educational Technology, 43(3), 428-438. http://dx.doi.org/10.1111/j.1467-8535.2011.01195.x

Yu, A. Y., Tian, S. W., Vogel, D., \& Kwok, R. C. W. (2010). Can learning be virtually boosted? An investigation of online social networking impacts. Computers \& Education, 55, 1494-1503. http://dx.doi.org/10.1016/j.compedu.2010.06.015

Yusof, M., Sandhu, M. S., \& Jain, K. K. (2008). Entrepreneurial inclination of university students: A case study of students at Tun Abdul Razak University (UNITAR). UniTAR e-Journal, 1-14.

\section{Copyrights}

Copyright for this article is retained by the author(s), with first publication rights granted to the journal.

This is an open-access article distributed under the terms and conditions of the Creative Commons Attribution license (http://creativecommons.org/licenses/by/3.0/). 